\title{
A Multidisciplinary Treatment for Morbid Obesity: Therapeutic Experience with Groups
}

\author{
Luciana Gaudio Martins Frontzek ${ }^{1}$, Marconi Moura Fernandes' ${ }^{2}$, \\ Mateus Eduardo Joanes Gomes ${ }^{3,4}$ \\ ${ }^{1}$ Salgado de Oliveira University, Belo Horizonte, Brazil \\ ${ }^{2}$ Post Graduate in Schizoanalysis and Institutional Analysis by Foundation Gregório Baremblitt, Belo Horizonte, \\ Brazil \\ ${ }^{3}$ Language \& Literature Course of UFMG, Federal University of Minas Gerais, Belo Horizonte, Brazil \\ ${ }^{4}$ Pontifical Catholic University of Minas Gerais, Belo Horizonte, Brazil \\ Email: lucianagaudio@yahoo.com.br, marconimf@yahoo.com.br, zanbattou@yahoo.ca
}

Received 3 April 2014; revised 1 May 2014; accepted 29 May 2014

Copyright (C) 2014 by authors and Scientific Research Publishing Inc.

This work is licensed under the Creative Commons Attribution International License (CC BY).

http://creativecommons.org/licenses/by/4.0/

(c) (i) Open Access

\section{Abstract}

This article reports the experience preparing a morbidly obese group to undergo bariatric surgery in a private healthcare plan in Brazil. The method used was based on assumptions of the operative groups by Pichon-Rivière (1998) and in psychoanalysis. The results have been satisfactory indicating that the multidisciplinary model, organized by the perspective of the operating group, is a viable alternative to intervention with morbidly obese patients.

\section{Keywords}

Morbid Obesity, Multidisciplinary Treatment, Psychoanalysis, Operative Groups, Bariatric Surgery

\section{Introduction}

In the year 2000 the World Health Organization (WHO) declared obesity a world epidemic (WHO, 1997). Because of the risks and comorbidities that obesity carries, it is considered an important public health problem (Nunes, Appolinario, Galvão, \& Coutinho, 2006). That is due to the increase in obesity numbers in large portions of the world. Besides, morbid obesity is included in the International Classification of Diseases (ICD 10), and it differs from an eating disorder, although the occurrence of eating disorders may be commonly associated to obesity, e.g., Binge Eating Disorder (BED). For those reasons, interest in the theme and in prevention and 
treatment methods increases on a daily basis.

Brief clarification becomes necessary on the concept of obesity and on the main treatments currently in use to contextualize the discussion proposed in this article: presenting and reflecting about how a multidisciplinary treatment, including therapeutic approach, may contribute for the reduction on postsurgical complications of obesity based on the experience with operative groups.

Body Mass Index (BMI) is acknowledged as an international standard to assess the level of obesity. The method has the advantages of being simple to calculate and not requiring instruments. Nevertheless, the Brazilian Society of Endocrinology and Metabolism (SBEM) (2009: pp. 11-12) indicates the limitations of the method, although it acknowledges it as a good indicator. The BMI is obtained by dividing one's body weight by height squared and originates the classification seen in Table 1.

Morbid obesity bears a strict relation with other diseases. Obesity is associated with some of the most prevalent diseases in modern society. The higher risk is that of developing diabetes mellitus (Brusch, 1973; IASO, 2013; Francischi et al., 2000). Studies show that there are multiple causes for obesity and they cover social, dietary, and environmental factors, genetic predisposition, and psychological issues, among others (Tamura, 2013; Santos, 2012; Francischi et al., 2000; Barbieri, 2012; Crispim, 2010; Fonseca-Junior, 2013; Teixeira \& Maia, 2011).

Obesity, defined as the excessive accumulation of body fat, derives from a chronic imbalance between energy ingested and energy spent. In such imbalance, several factors may be implied related to life style (diet and physical activity) and neuroendocrine alterations, together with hereditary component (Nunes et al., 2006: p. 299).

Current society paradoxes also constitute factors that contribute for the aggravation of the disease. At the same time the beauty standard of a thin body is "required", consumption of unhealthy food is also stimulated (Goldenberg, 2011; Conti, 2008; Nascimento, Bezerra, \& Angelim, 2013; Castro, Chinelato, \& Ferreira, 2013).

Obesity is a disease with multifactorial etiology, thus, conventional treatment requires several approaches which are, namely, nutritional, psychological, endocrinological and also the inclusion of physical activity in the attempt towards weight loss. Surgical methods are only indicated for cases when weight loss cannot be reached through physical activity or clinical and ambulatory follow up (Fandiño et al., 2004).

However, in practice, the disease is many times not approached in an effectively multidisciplinary way so that one could intervene upon the complexity of its clinical background. In the next topic we shall talk about the characterization of the main clinical approaches of intervention onto obesity, in the presumption of justifying that all of them are important and, mainly, emphasizing the need of working together in a multidisciplinary way in opposition to the conventional logics of fragmented work.

\section{Obesity and Clinical Interventions for Treatment}

The Ministry of Health (MS) acknowledges the need of surgery for morbidly obese people and sets criteria for the indication of surgery, which are: suffering from high proportions of obesity, with BMI higher than $40 \mathrm{~kg} / \mathrm{m}^{2}$ (obesity level III, severe); and below that index (up to BMI 35), in case of existing comorbidities, with no age restriction and having attempted clinical treatment for over two consecutive years, unsuccessfully.

Although surgical intervention is an aggressive action and has high risks, in many cases keeping obese represents an even higher risk due to the comorbidities brought to the health of the individual by excessive weight. Some authors highlight the need of a multidisciplinary team to ensure the success of the surgery (Souza, Barreto, Santos, Liberali, \& Navarro, 2008).

Table 1. Classification and risks of associated diseases, according to BMI.

\begin{tabular}{ccc}
\hline BMI $\left(\mathrm{kg} / \mathrm{m}^{2}\right)$ & Classification & Comorbidity risk \\
$18.5-24.9$ & Normal & Medium \\
$25.0-29.9$ & Pre-obese & Increased \\
$30.0-34.9$ & Obesity level I & Severe \\
$35.0-39.9$ & Obesity level II & Very severe \\
$\geq 40.0$ & Obesity level III (morbid) & \\
\hline
\end{tabular}


Conventional treatment must be always the first choice, mainly in cases started recently and with no history of proper previous treatment. Unfortunately, the rate of lack of success of conventional treatment is high, and failure is observed in over $90 \%$ of the cases. Surgical treatment is, currently, the alternative with the best results, although there are complication risks in the short, medium and long term, if strict clinical, nutritional and psychological follow-up with an experienced multidisciplinary team is not performed (Nunes et al., 2006: p. 342).

There are several kinds of surgeries nowadays, divided into three groups, basically: restrictive, disabsortive and combined surgeries. One of the most performed is the bariatric surgery, also known as Fobi-Capella or (conventional or laparoscopic) gastroplasty (Stol, Dadan, Gugelmin, \& Ropelato, 2013; Leal, Franca, \& Navarro, 2010; Baratieri, Onzi, Kremer, \& Josino, 2013; Mônaco, Merhi, Aranha, Brandalise, \& Brandalise, 2006). The technique employed in it is mixed and its main objective is restricting the stomach capacity to receive food and reducing food contact area for nutrient absorption, then, being restrictive and disabsortive.

To perform the bariatric surgery a complex preparation is necessary, which requires adequate performance. Surgery is only one part in a larger process that involves changing feeding and emotional habits (Souza et al., 2013). This way, professional assistance is necessary for the patient (mainly a psychologist and a nutritionist follow-up associated to medical follow-up) so that he may implement the necessary changes of habits in his life, in a way he may give them continuous maintenance. Literature (Monteiro \& Angelis, 2007; Luz \& Encarnação, 2008; Souza et al., 2008) of the area indicates the need of a multidisciplinary team for the treatment of obesity, but to ensure effectiveness to the treatment the team must interact and their members must have similar conduct. There are people suffering from morbid obesity who are followed up by several professionals, sometimes from the same institution. But the fact of having a patient in common does not make them a team, for they do not discuss the case and, many times, not even agree as to each other's conduct causing doubts in the patient, while having a partial view on the patient, for they only know the opinion of other professionals through reports. Travado, Pires, Martins, Cidália, and Cunha (2004) alert us towards about the fact:

Difficulty in maintaining the weight lost in the long term, added to the frustration of those treatment regimes are shared by almost every obese who, this way, continue to gain weight. This type of treatment failure for this disease is largely due to its unimodal character, where biological, biochemical and prescriptive interventions characteristic of the medical model are privileged, to the detriment of the psychosocial factors of the individual in his process of disease and treatment (Reis, 1998). The psychological variables, namely, the personality variables, seem to play an important role in this disease (Grana, Coolidge, \& Merwin, 1989), so that a therapeutic approach that addresses the biopsychosocial dimensions of the individual through a multidisciplinary team must be privileged to assure success in the treatment of that disease and in its long-term maintenance, contributing to improved health, quality of life, well-being and satisfaction of the individuals suffering from it (Travado et al., 2004: p. 533).

Primarily, physical activity helps in weight loss and, in the long term it has the advantage of contributing for its maintenance, besides other benefits to health (Ades \& Kerbauy, 2002). But nutritional follow up is necessary, given the fact that bad feeding habits are one of the causes of obesity. Nevertheless, if therapeutical follow up does not take place, the patient will, too much often and due to lack of emotional management, not accomplish the dietary reeducation plan, once anxiety, psychic compensation, the "compensation through eating", among other factors, will sabotage the process.

Food reeducation differs from the popular diets-which are nutrient restrictive and temporary-due to the fact it is a reeducation that aims to permanent and well-balanced changes, so that it can meet the body needs. In contrast, food and eating are configured as affection drivers and, thus, have clear implication on the subject's emotional side. This way, a change in food pattern is directly proportional to the psychological management acquired, among other variables.

For a successful feeding plan, the multi professional team has important roles along the whole treatment. They are: Motivating the obese individual towards weight loss; knowing his history of failures and successes; observing the support from family and friends; monitoring comorbidities. (...) minimizing the difficulties and resistance the individual may have to the treatment, as well as observing his economic condition (Nunes et al., 2006: p. 316).

Besides, psychological follow-up is fundamental so that the patient may be able to notice the amplitude of the 
process he will go through and to help him take more conscious decisions, more in accordance with his situation. Bariatric surgery must be contra indicated in any case when the patient does not fully agree with the surgery or is not able to evaluate the changes that will take place after it, either due to psychiatric disorders or to cognitive inability (Campagnolo et al., 2013; de Oliveira et al., 2004).

Thus, a treatment of morbid obesity, either surgical or not, that ignores such aspects has a large chance of failing or not sustaining itself in the long-term (Barros, Moreira, Frota, \& Caetano, 2013). Once that clarification is made, we shall report the experience in the group work performed with morbidly obese patients who are candidates to bariatric surgery, in a private health care plan - which is a service company in the area of Complimentary Health Care—in Belo Horizonte, Minas Gerais—Brazil.

\section{Group Participants' Characterization}

All the group participants are morbidly obese and indicated to the group after medical assessment that verifies if candidated fulfill the surgery indication criteria according to the standards established by the Ministry of Health and the Brazilian Society for Bariatric Surgery and Metabolism (Sociedade Brasileira de Cirurgia Bariátrica e Metábolica-SBCB):

- BMI above $40 \mathrm{~kg} / \mathrm{m}^{2}$, independently of the presence of comorbidities.

- BMI between 35 and $40 \mathrm{~kg} / \mathrm{m}^{2}$, in the presence of comorbidities.

- BMI between 30 and $35 \mathrm{~kg} / \mathrm{m}^{2}$ in the presence of comorbidities which are obligatorily classified as "severe" by a medical specialist in the respective area of the disease. It is also mandatory the finding of "lack of clinical response of obesity" by an endocrinologist.

- Presenting BMI and comorbidities at risk range, for at least two years, and having undergone previous conventional treatments. Besides, having had failure or recurrent weight, verified by data collected from the patient's clinical report.

- Age ranging from 18 to 65 .

- Groups are predominantly made up of women.

- They are predominantly from middle class.

\section{Methodology in the Preparation Groups for Bariatric Surgery and Theoretic Grounding}

The preparation groups for bariatric surgery are constituted in a Private Health Care Plan in Belo Horizonte, and developed by a multidisciplinary team composed of a psychologist, a nutritionist, a surgeon, a social worker, an endocrinologist and a pulmonologist, since 2006. To guide the group were used the notions on operative groups proposed by Pichon-Rivière (1998) and the psychoanalytical assumptions created by Freud. In the methodology of operative groups six vectors are proposed for analysis and group intervention, which are: belonging, cooperation, pertinence, communication, learning and tele (empathy/emotional climate). Within that perspective the Operating Conceptual Referential Scheme-OCRS (Esquema Conceptual Referencial y Operativo-ECRO) of the group is built along the process, once its own working rules are being delineated and strengthened along the process (Pichon-Rivière, 1998).

A group therapy agreement is established at the beginning of works. One of the propositions is being open to the analysis of the information available on the theme, but leveling with those that will best help the group in the self-care task, so that they can focus on that objective and on information pertinence in their daily lives. Operating rules such as schedules, structuring, frequency, adherence, respect in listening and speaking and confidentiality are the main subjects approached.

The objective of the group is preparing the candidate for the stomach reduction surgery, in all necessary fields: psychological, nutritional, physical and functional. Each group has minimum 5 (five) and maximum 10 (ten) participants. Patients are individually accommodated and screened, by means of psychological and nutritional consultation, before they can subscribe in the group. During the nutritional assessment an individualized feeding plan is made and in the psychological screening a semi-guided interview is conducted and Eating Disorder Scales are used: Binge Eating Scale-BES (Gormally, Black, Daston, \& Rardin, 1982, adapted in Brazil by Freitas, Loppes, Coutinho, \& Appolinario, 2001) and Body Shape Questionnaire-BSQ (Cooper et al., 1987, translated into Portuguese by Di Pietro, Xavier, \& Silva, 2003, in Nunes et al., 2006). These questionnaires were chosen base on studies that indicated higher incidence of those issues within morbid obese: 
A set of evidence suggests that compulsive eating, followed or not by compensatory maneuvers for weight control, as well as body image alterations, are the most frequent forms of eating psychopathology in this group (Nunes et al., 2006: p. 368).

The weight of the participants is measured each 15 days and all are given a follow-up card developed so that the guardian may follow, besides weight measurements, also the blood pressure and blood glucose test.

In the preoperative, meetings are held each fortnight, and last one hour and thirty minutes each. They are therapeutical and informative meetings. Although there are specific days in the schedule for therapeutic work performed by the team psychologist, there are always psychological group interventions in the first thirty minutes. The objective of that space is strengthening the therapeutical bond with the group and among themselves, as well as managing upcoming demands relative to the group task. In that first moment of the meeting, they are given the chance of sharing daily life facts, either negative or positive, either related or not, with obesity. That proposition resembles free association, a technique proposed by psychoanalysis with the purpose of mobilizing unconscious content which, as such, are not easily accessible. "Our unconscious erupts when we expect the least, amidst our most rational action” (Campos et al., 2013: p. 24), then, understanding that proposition helps up comprehend why the patient, even after agreeing with the guidance he must follow to take better care of himself, does not put the treatment in practice. That unconscious content derives from constructs that integrate the cultural influence, social pressure, personal choices, among others. This way, making room so that the unconscious may erupt is acting towards the effective acquisition of self-care,

Assuming that people, the patients and the health care workers also act driven by unconscious reactions, unknown to themselves and upon which they do not have entire control, changes the way we approach health care teams and the relations developed there. The recognition of the unconscious dimension changes our analyses (Campos et al., 2013: pp. 23-24).

In the scope of the groups there is also a meeting with the family before undergoing the surgery. In that meeting, held only with family members, possible doubts and fears are approached regarding the treatment process which the patient will undergo. Besides the necessary clarification, they are also invited to adhere to the food reeducation for their benefit and to create favorable conditions for the candidate to surgery. Creation/strengthening of that support network is encouraged also as a form of prevention, through the stimulus to change habits cultivated by the family.

In the postoperative, the meetings are held on a monthly basis and continuity is given to its therapeutical character, alternated with nutritional guidance and medical follow-up that, together with the patient's evolution, follows with increasing periodicity.

The Informed Consent Form is delivered and discussed in the group. This moment the possibility of disclosing the group for research purposes is clarified. Then, having found that all the principles of ethics in research and academic disclosure with human beings have been respected, the participants signed the ICF.

\section{Report on Group Work for Habit Change}

When the patients arrive for psychological individual assessment they bring a set of information, labels and medical diagnoses that are, often, used as protective shields to their real implication in the process of obesity. We seek to give them space, by means of clinical listening, so that the emotional dynamics of the patient may start to emerge. The secondary gains the disease brings, the unconscious motivation that maintains it and the defense mechanisms that were built around it, are fundamental elements to a full understanding around that patient's disease. When following up those patients for bariatric surgery this reality reveals itself clearly, for

Surgery is only a moment in a much wider process, whose success is only whole when the patient shows himself able to make maximum use of the benefits of weight loss, and that result, in large part, depends on external and internal changes performed by the individual himself. It is this feature of the process that makes space for the participation of Psychology in the terrain of surgical interventions aimed to reach weight loss (Benedetti, 2003: p. 68).

Experience with the groups in this preparation for surgery showed very satisfactory. Besides the therapeutical bond, which privileges psychological elaboration, subjective rectification and implication in the treatment, a group bond is formed capable of reassigning meaning to one's experience from the moment that person shares 
and problamatizes his issues in the group. Once in the group, a mutual support networks is established that collaborates for the persistence in changing habit. The fact of not having that network is appointed by the majority as one of the causes of failure in previous methods (discontinuity of treatment). Belonging, a unique sensation of being part of a group, makes the person take responsibility, become assiduous and respect the commitments made once that person acknowledges her importance in the group (Pichon-Rivière, 1998).

It is also noted that the placement of information, in different ways, not only in expository ways, through group techniques, messages in slide films, videos and the presence of people invited to speeches, always under invitation and towards problematization, allows more effective assimilation of the content. The fact that information is repeated many times, in diverse ways, and transmitted in the long-term, facilitates the elaboration and permits the implementation of the changes necessary. Another relevant factor that goes beyond the simple placement of information is the stimulus for them to participate, speak what they think, express how they see the issue in their own reality. Group members are constantly invited to appropriate knowledge and share with everybody the way they understand that information.

Whenever one of the participants reports on his difficulties, it is noticed that the group itself becomes able to mobilize itself and encourage the colleague by sharing similar difficulties, victories, among others. Some times, for some reason, a participant may not ask about some doubt he may have had during the meeting and, on their leave, they contact the colleague to ask him about the theme. It is common having people exchange hints, ideas and insights, within the group, on victories and/or to face difficulties found in their daily lives, once they experience similar situations due to the common clinical status of obesity. The affective bonds built in the group are great encouragement for changing habits. It is common having reports at the meetings expressing how much they feel sheltered, comfortable, and inserted for being part in that group. The feeling of belonging is facilitated by the fact that people have similar experience and purposes, what generates positive transfer.

When, in individual psychological screening or in the group itself, it is noticed that a participant has emotional disorders that require individual intervention, or even when he has issues which he would rather not bring up collectively, he is sent to have his individual psychological follow-up session simultaneously to the group meeting.

Another conduct with the objective of making them the main characters in the process is the moment we are about to announce the first one who shall undergo surgery. They are clarified that the professionals will provide technical reports, but the true liberation for surgery is provided by the patient to himself through the conducts built up to the moment. This way, around the seventh month of group meetings, the group is asked who they think is prepared to undergo surgery in that moment and the finding of such aspect is a very encouraging result for, in most cases, the group acknowledges who are the most dedicated people in the process and, thus, prepared for surgery. Each person has his own timing and the "liberation" is conceded in group by both professionals and patients. That timing is respected, thus, the surgical procedure will come at a time, depending on each person. There are cases of waiver, there are those who subscribe to new groups for not feeling comfortable for not being prepared or, even for not having been a frequent attendee, there are cases for which the team contraindicates surgery for the risks are not plausible, in the end, a myriad of individual cases must be considered. Even though, those cases are exceptions, most of the group manages to undergo surgery within 7 months to 1 year, approximately.

\section{Report on the Psychological Work Experience with the Group Participants}

In screening, which is done individually by the psychology department, the diversity of stories told is immense. In all of them, either at a lower or higher degree, it is possible to notice the relation between their personal journey and the obesity process. The reports make it clear that, ignoring the psychological and social aspect of the patient's involvement complicates the understanding of the course of the disease and, consequently, a higher effectiveness of professional practice.

Since 2006, approximately 200 patients have participated in the groups. It is common listening to reports that show some traumatic event as a trigger to the process of obesity. There are stories of sexual abuse, unwanted pregnancy, explicit prejudice, professional failure, among others. What emerges from these cases is that "fattening” appears as a defense mechanism to psychically protect them against some emotional threat, as states Kaufman (2005: p. 53), "obesity, according Alperovich (1988), could be seen as a somatic defense mechanism which acts as a protective cover for the world and emotions regarded as 'bad' ones by the patient”. 
One of the most recurring themes within this audience is body image, i.e., the image of our own body which we form in our minds (Sant'Ana, 2001b; Schilder, 1994). The group members often report they do not take pleasure looking in the mirror, taking a picture, in the end, they say they avoid contact, both visual and physical, with their own body. This way the distance between the body perceived by others and the body imagined keeps getting bigger. This aspect needs to be worked before, and after, the surgical procedure, for, when they have stomach reduction done weight loss is usually drastic, a fact that could worsen the distortion of their body image and could generate psychological disorders (Coltro, 2000; Dolto, 2001).

Many come to the group introverted, shy, insecure and gradually allow themselves go, actively integrating the process. It can be noticed that behavior change is the result of internal changes that begin to bloom. It is common having patients ascribing the reason for much of their difficulties to obesity, even those who do not depend on such difficulties. After surgery, then, the chance of the patient becoming frustrated when he finds that stomach reduction will not solve all of his problems is very large. Investing in the therapeutic process is working on the prevention of future psychological grief. It is encouraging for the staff monitoring patients who, for years, could not dance in public or could not enter in a swimming pool, for example, do these activities before undergoing surgery. We can notice that the group meetings help those patients to rescue that which is not connected to morbid obesity. We also see this strengthening in self-esteem and autonomy in the transformations which visibly happen throughout the sessions. Many women, who once appeared apathetic, without vanity (with their hair always tied) begin to have their hair cut, to dye it in another color, to wear makeup and more youthful clothing.

All patients enrolled in the group have a history of several failed attempts at weight loss, for this finding is one of the criteria to undergo bariatric surgery. The main treatment attempts are reported to be medicine, nutritional and clinical based. The differentials mentioned by them in the treatment proposed by the health care plan are: the fact of being in a group, the fact of being in a team, and the fact of effectively having the action of a psychologist in all stages of the process. It is almost unanimity among them the approval of the space to be heard.

We have also witnessed cases when not even surgery would make the person leave the morbidly obese status. How to explain the fact that a person would have undergone the surgery, without any medical complication, and still has not had the weight loss expected? Without having a view expanded by theories such as psychoanalysis, which considers a person's life story and his unconscious determinations, it would not be possible to understand stories like those. The defense mechanism built around obesity has a protective function, and it takes time to work them in a way that the person may feel psychologically secure to carry other meanings (Sant'Ana, 2001a). That the staff is trained and that the patient follows the nutritional and medical advice is not enough for success in the treatment of obesity. There must be a desire to unbuild the symptoms involved, which have a protective character and that include secondary gains, because if not, the emotional aspect may predominate in the results obtained. It is also necessary that health care professionals provide support so that the patient can create his own demand for change. Each person has his unconscious motivations and only that person can give the final endorsement for the actual success of morbid obesity treatment. A treatment that addresses the subjectivity of the individual provides him with more opportunities to make choices different from those he may have done up to that moment.

As mentioned before, the need for a psychologist in health care multidisciplinary teams is increasingly noticed. This professional, by bringing a subjective look to the understanding of the behavior or to the outcomes of medical intervention towards the patient, performs the junction of the fragmented vision to which the patient is exposed, giving voice to the subject beyond his physical disease,

When working with obesity it is important to remember that it fulfills a social, psychological and relational role in the life of the obese. When obesity is removed, what is left to the patient? How to deal with this new identity, that of a non-obese person? (Kaufman, 2005: p. 92).

As mentioned above, we notice that the operational mode of these patients is, in many respects, similar. They have a large tendency to hide their problems and/or project them out of themselves. It is a retreat in the face of coping with the challenges everyone has in their daily lives. It is common to hear statements like these: "It's my stubborn husband's fault, he who won't let me go on", "My mother never gave me attention and that's the reason why I am like this", "neither the medical and/nor the nutritional treatment worked" and many other similar statements. In extreme cases, such as abuse, for example, that retreat is usually more violent and one relinquishes living fully to "hide" indefinitely. In these cases, it is necessary to mediate the process so that greater aware- 
ness may happen and these patients may realize the choice is still theirs and, especially, that they can choose changing the route.

As a consequence of that psychological dynamics, the search for treatment also relies on something that will come from out of them. It is the surgery, it is the medicine, it is the doctor, it is the group that will "cure" me, but reading between the lines, "I do not have to make any effort, this is not about me." This way of thinking becomes clear when we hear the following statements: "I’ve already tried everything, but I can't lose weight”, "I eat little, I don't know why I'm fat", among others. On the other hand, concomitantly with that behavior, it can be noticed that the health care team itself assumes the position of saying "do exactly as I'm telling you to and it will work because I know what's best for you”, reinforcing the patient's alienation about his own process.

Thus, the follow-up group aims to carry the implication of the subject with his illness and the related grievance, favoring his decision-making process in a more positive and healthy way. By following the assumptions of Freire (2006: p. 22), it can be understood that teaching is not about transferring knowledge, but about creating possibilities for its production or construction. Caution, sensitivity and delicacy are required so that the team may be a travel companion in each participant's personal process, once transformation we strive for to happen, many times, implies divesting oneself of defenses built and nurtured along long time, which creates the sensation of uncertainty and defenselessness. Therefore, so that there may be enough intrinsic motivation to carry on the change, one must have the confidence that other paths are possible, and that confidence will come through the transcendence of mere information, it will come within a context that involves many elements such as presence, bond, and encouragement to autonomy, among others.

Obesity is a topic of growing interest and psychology has much to contribute to its understanding, prevention and treatment. Dialogue is necessary with other areas of knowledge, because through experience with groups, the importance of multidisciplinary work with these patients has became clear.

It is impossible thinking of an effective treatment for obesity without a radical change in dietary patterns and physical activity. And for those changes to happen, in most cases, having medical intervention is just not enough. There is increasing awareness that obesity treatment is a multidisciplinary action and that there is no magic formula or medication capable of providing long-term satisfactory results without a complete change of habits by the patient (Nunes et al., 2006: p. 289).

Bariatric surgery is emerging as a drastic alternative to morbid obesity, but it is being trivialized. In large part of the surgeries performed, there is no rigor in adequate preparation of the patient, since it should involve nutritional, medical, psychological and social aspects. What is being aimed is only weight loss without considering the complications that can occur after surgery due to the lack of adherence of the patient to food reeducation, once the achievement of greater emotional management is not worked together with him.

However, bariatric surgery requires a strong adherence of the patient to its post-surgical requirements (i.e., dietary, behavioral and lifestyle changes) to ensure the effectiveness of the treatment. As mentioned by Valley and Grace (1987) an obese who achieves significant weight loss, but who continues eating compulsively precipitating medical complications, cannot be considered a therapeutic success, i.e., it is an incomplete process in which the behavioral variables were neglected (Travado et al., 2004: p. 534).

Morbid obesity is an issue that requires scientifically grounded studies and fruitful discussions among the areas so that its understanding may advance, then providing worldwide preventive actions. As mentioned throughout the article, some emotional aspects are crucial in the profile of this public. Travado et al. (2004), point some psychological features of morbidly obese patients that should be considered for their surgical treatment:

Studies on the psychological characteristics of this population refer, as the most frequent changes, at the psychopathological and the personality levels, the borderline disorder (Black, Goldstein, \& Mason, 1992) and at emotional level, those of depressive type, being the anxious type the second most prevalent (Black, Goldstein, \& Mason, 1992; Glinski, Wetzler, \& Goodman, 2001). Psychoticism is virtually absent (Glinski, Wetzler, \& Goodman, 2001). Compulsion to eat (binge-eating) is one of the most disturbing and pervasive behavioral changes, being the food ritual accompanied in most of these patients, by emotional reactions of irritability, disinhibition and anger (Lang et al., 2000). Several authors reported other psychological complications associated with obesity. For example, Stunkard and Wadden (1992) refer to distorted body image, 
low self-esteem, discrimination/social hostility, feelings of rejection and social exclusion, functional and physical problems, history of sexual abuse, early parental loss, alcohol abuse family history, suicidal ideation, family/marital issues, feelings of shame and self-blame, aggressiveness/rebellion, dissatisfaction with life, social isolation, absenteeism, psycho somatization, among others (Travado et al., 2004: p. 534).

Thus, experience shows that group work is an effective alternative that offers a number of benefits, as the support network that is formed between them, learning through the exchange of knowledge, the unveiling of the unconscious, among others. Mello et al. (2004) conducted a study comparing the effects of obesity treatment when conducted in groups and when only conducted at the ambulatory and results also point to the effectiveness of the methodology:

Good results can be achieved in an intervention that, by being applied to groups, may benefit a larger number of subjects by having professionals engaged in the same service. (...) Group care service in an educational program in nutrition and health, was as or more effective than individualized care in a reference ambulatory, establishing itself as an alternative treatment for obesity (Mello et al., 2004: p. 468).

This way, the preparation of candidates to stomach reduction surgery in group proves more feasible and multidisciplinarity becomes necessary.

\section{Conclusion}

Data obtained in the experiment show positive results of multiprofessional preparation and group preparation of candidates to bariatric surgery. Health reeducation performance proved feasible through the therapeutic group. Promoting the autonomy of the subject through the therapeutic process, connected to other approaches (nutritional, medical and physical activity) provides more possibilities so that the subject can maintain the long-term results, since many patients return to obesity after surgery.

The report of this experience aims to provide reflections on possible paths to guide health care professionals who deal with this audience and it also intends to awaken people to the importance of global care with obesity and proper pre-surgical preparation, when surgery is really necessary.

\section{References}

Ades, L., \& Kerbauy, R. R. (2014) Obesidade: Realidade e indagações. Psicologia USP, 13. http://www.researchgate.net/publication/26364277 Obesidade realidades e indagaes/file/d912f50f6e14b9d319.docx\&sa =X\&scisig=AAGBfm2p-LPPU6lXcwfdFi878Qv6sR3srQ\&oi=scholarr\&ei=lNtVU83mM8HgsASH-oCgBQ\&ved=0CC4 QgAMoADAA

Baratieri, R., Onzi, T. R., Kremer, G., \& Josino, T. F. (2013). Resultados iniciais da perda do excesso de peso e redução de comorbidades em obesos mórbidos submetidos à gastrectomia vertical laparoscópica. Arquivos Catarinenses de Medicina, 42, 9-14.

Barbieri, A. F. (2012). As causas da obesidade: Uma análise sob a perspectiva materialista histórica. Conexões: Revista da Faculdade de Educação Física da UNICAMP, 10, 133-153.

Barros, L. M., Moreira, R. A. N., Frota, N. M., \& Caetano, J. A. (2013). Mudanças na qualidade de vida após a cirurgia bariátrica. Revista de Enfermagem UFPE on Line, 7, 1365-1375.

Benedetti, C. (2003). De obeso a magro: A trajetória psicológica. São Paulo: Vetor.

Brandalise, N. A. (2006). Impacto da cirurgia bariátrica “tipo capella modificado” sobre a perda ponderal em pacientes com obesidade mórbida. Revista de Ciências Médicas, 15, 289-298.

Brazilian Society of Endocrinology and Metabolism (SBEM) [Sociedade Brasileira de Endocrinologia e Metabologia] (2009). Diretrizes brasileiras da Associação Brasileira para o estudo da obesidade e da síndrome metabólica 2009/2010. http://www.abeso.org.br/pdf/diretrizes brasileiras obesidade 20092010 1.pdf

Brusch, H. (1973). Eating Desordes: Obesity, Anorexia Nervosa, and the Person within. New Yorj: Basic Books.

Campagnolo, C. Q., Beatriz, K., Prateado, L. M., Di Lascio, R. G., \& Heller, D. C. L. (2013). A influência do acompanhamento psicológico na visão de cirurgiões bariátricos na cidade de Curitiba.

http://www.psicologia.pt/artigos/textos/A0247.pdf

Campos, R. O., Massuda, A., Valles, I., Castano, G., \& Pellegrinio, O. (2013). Psicanálise e saúde coletiva. São Paulo: Hucitec.

Castro, M. R., Ferreira, V. N., Chinelato, R. C., \& Ferreira, M. E. (2013). Imagem corporal em mulheres submetidas à cirurgia bariátrica: Interações socioculturais. Motri, 9, 82-95. 
Coltro, A. (2000). A fenomenologia: Um enfoque metodológico para além da modernidade. Caderno de Pesquisas em Administração, 1, 37-45.

Conti, M. A. (2008). Os aspectos que compõem o conceito de imagem corporal pela ótica do adolescente. Revista Brasileira de Crescimento e Desenvolvimento Humano, 18, 240-253.

Crispim, M. A. C. (2010). Determinantes da obesidade na pobreza: Regência da acumulação do capital. Thesis, Maceió: Universidade Federal de Alagoas (Faculdade de Serviço Social).

de Oliveira, V. M., Linardi, R. C., \& Azevedo, A. P. (2004). Cirurgia bariátrica: Aspectos psicológicos e psiquiátricos. Revista de Psiquiatria Clinica, 31, 199-201.

http://scholar.google.com.br/scholar_url?hl=pt-BR\&q=http://www.revistas.usp.br/rpc/article/download/16270/17982\&sa= X\&scisig=AAGBfm2ywNXB-JFn3-Ns2QLLSxdgY2-Cw\&oi=scholarr\&ei=SdNVU4TTAcfLsATN3oDgCg\&ved=0CDI QgAMoATAA

Dolto, F. (2001). A imagem inconsciente do corpo. São Paulo: Perspectiva.

Fandiño, J., Benchimol, A. K., Coutinho, W. F., \& Appolinário, J. C. (2004). Cirurgia bariátrica: Aspectos clínicos-cirúgicos e psiquiátricos. Revista de Psiquiatria, RS, 26, 47-51. http://www.scielo.br/pdf/rprs/v26n1/20476.pdf

Fonseca-Junior, S. J., Sá, C. G. A. B., Rodrigues, P. A. F., Oliveira, A. J., \& Fernandes-Filho, J. (2013). Exercício físico e obesidade mórbida: Uma revisão sistemática. Arquivos Brasileiros de Cirurgia Digestiva (São Paulo), 26, 67-73. http://dx.doi.org/10.1590/S0102-67202013000600015

Francischi, R. P. P., Pereira, L. O., Freitas, C. S., Klopfer, M., Santos, R. C., Vieira, P., \& Júnior, A. H. l. (2000). Obesidade: Atualização sobre sua etiologia, morbidade e tratamento. Revista de Nutrição, 13, 17-28. http://dx.doi.org/10.1590/S1415-52732000000100003

Freire, P. (1996). Pedagogia da autonomia. São Paulo: Paz e Terra.

Freitas, S., Lopes, C. S., Coutinho, W., \& Appolinario, J. C. (2001). Tradução e adaptação para o português da Escala de Compulsão Alimentar Periódica. Revista Brasileira de Psiquiatria, 23, 215-220.

http://www.scielo.br/pdf/rbp/v23n4/7169.pdf http://dx.doi.org/10.1590/S1516-44462001000400008

Goldenberg, M. (2011). Cultura e gastro-anomia: Psicopatologia da alimentação da alimentação cotidiana. Entrevista com Claude Fischler. Horizontes Antropológicos, 17, 235-256. http://dx.doi.org/10.1590/S0104-71832011000200010

IASO (International Association for the Study of Obesity) (2012). Obesity the Global Epidemic. Obesity \& Research. http://www.iaso.org/iotf/obesity/obesitytheglobalepidemic/

Kaufman, A. (2005). O obeso no prato. São Paulo: Segmento Farma.

Leal, C. M. S., Franca, P. M. F. M., \& Navarro, A. C. (2010). Cirurgia bariátrica, uma análise sobre este tratamento no controle da obesidade. Revista Brasileira de Obesidade, Nutrição e Emagrecimento, 4, 46-53.

Luz, D. M. D., \& Encarnação, J. N. (2008). Vantagens e desvantagens da cirurgia bariátrica para o tratamento da obesidade mórbida. Revista Brasileira de Obesidade, Nutrição e Emagrecimento, 2, 376-383.

Magdaleno, R. (2009). Características psicológicas de pacientes submetidos a cirurgia bariátrica. Revista de Psiquiatria, 31, 73-78.

Mello, E. D., Luft, V. C., \& Meyer, F. (2004). Atendimento ambulatorial individualizado versus programa de educação em grupo: Qual oferece mais mudança de hábitos alimentares e de atividade física em crianças obesas? Jornal de Pediatria, 80, 468-474.

http://www.scielo.br/scielo.php?script=sci_arttext\&pid=S0021-75572004000800008\&lng=en\&tlng=pt.10.1590/S0021-75 $\underline{572004000800008}$

Mônaco, D. V., Merhi, V. A. L., Aranha, N., Brandalise, A., \& Brandalise, N. A. (2006). Impacto da cirurgia bariátrica tipo capella modificado sobre a perda ponderal em pacientes com obesidade mórbida. Revista de Ciências Médicas, 15, 289298.

Monteiro, A., \& Angelis, I. (2007). Cirurgia bariátrica: Uma opção de tratamento para a obesidade mórbida. Revista Brasileira de Obesidade, Nutrição e Emagrecimento, 1, 19-26.

Nascimento, C. A. D., Bezerra, S. M. M. S., \& Angelim, E. M. S. (2013). Vivência da obesidade e do emagrecimento em mulheres submetidas à cirurgia bariátrica. Estudos de Psicologia (Natal), 18, 193-201. http://dx.doi.org/10.1590/S1413-294X2013000200004

Nunes, M. A., Appolinario, J. C., Galvão, A. L., \& Coutinho, W. (2006). Transtornos alimentares e obesidade. Porto Alegre: Artmed.

Pichon-Rivière, E. (1998). Teoria do vínculo. São Paulo: Martins Fontes.

Sant’Ana, D. B. (2001a). Corpos de passagem. São Paulo: Estação Liberdade. 
Sant’Ana, D. B. (2001b). Políticas do corpo. São Paulo: Estação Liberdade.

Santos, A. X. (2012). Revalência de hipertensão arterial sistêmica e diabetes mellitus em obesos candidatos à cirurgia bariátrica. Revista Brasileira de Obesidade, Nutrição e Emagrecimento, 6, 184-190.

Santos, R. (2009). Apoio psicológico pode evitar recaídas na cirurgia bariátrica. Jornal da Unicamp.

Schilder, P. (1994). A imagem do corpo (2nd ed.). São Paulo: Martins Fontes.

Sociedade Brasileira de Cirurgia Bariátrica (2014). http://www.sbcb.org.br/cbariatrica.php?menu=5

Sousa, M. M., Araújo, A. A., Silva, E. P., Melo, F. A. B. P., \& Gouveia, R. A. (2013). Projeto terapêutico singular a paciente de obesidade mórbida na atenção hospitalar: Estudo de caso. Revista de Enfermagem UFPE on Line, 7, 5638-5644.

Souza, M. G., Barreto, M. A. M. F. N., Santos, S. M., Liberali, R., \& Navarro, F. (2008). A importância da intervenção multidisciplinar no tratamento da obesidade mórbida considerando o acompanhamento nutricional pré e pós cirúrgico. Revista Brasileira de Obesidade, Nutrição e Emagrecimento, 2, 588-596.

Stol, A., Dadan, D. D., Gugelmin, G., \& Ropelato, R. V. (2013). Long Follow-Up of Patients with Gastric Band. Arquivos Brasileiros de Cirurgia Digestiva (São Paulo), 26, 13-16. http://dx.doi.org/10.1590/S0102-67202013000600004

Tamura, L. S. (2013). Avaliação clínico-funcional pré-operatória no quadro de obesidade mórbida. Campinas.

Teixeira, F., \& Maia, A. (2011). Factores preditores do insucesso na gastrobandoplastia: Uma revisão da literatura. Psicologia, Saúde \& Doenças, 12, 212-223.

Travado, L., Pires, R., Martins, W., Cidália, V., \& Cunha, S. (2004). Abordagem psicológica da obesidade mórbida: Caracterização e apresentação do protocolo de avaliação psicológica. Análise Psicológica, 22, 533-550.

http://www.scielo.gpeari.mctes.pt/scielo.php?script=sci_arttext\&pid=S0870-82312004000300010\&lng=pt\&nrm=iso

WHO (World Health Organization) (1997). Report of a WHO Consultation on Obesity. Obesity, Preventing and Management the Global Epidemic. Geneva: WHO. 